\title{
MEMAKNAI UNSUR NARATIF DALAM FILM PARASITE MELALUI PERSPEKTIF FILSAFAT KEBEBASAN MANUSIA
}

\author{
Rifqi Nadhmy Dhia ${ }^{1}$ \\ Firman Kurniawan²
}

Diterima Nov. 18, 2020; Disetujui April. 26, 2021.

\begin{abstract}
Abstrak: Manusia pada hakikatnya memiliki kebebasan sosial yang melekat pada dirinya. Film Parasite (2019) yang mengangkat isu sosial di Korea Selatan memiliki kaitan erat dengan realitas stratifikasi sosial dalam masyarakat. Dengan menggunakan film Parasite sebagai studi kasus, artikel ini berusaha menelusuri kecenderungan produksi makna mengenai filsafat kebebasan manusia. Dalam prosesnya artikel ini menarik kesimpulan bahwa penggambaran seseorang di dalam struktur sosial pada unsur naratif film Parasite dapat merepresentasikan makna tentang kebebasan sosial yang juga dibatasi oleh kebebasan manusia lain.
\end{abstract}

Kata Kunci: Komunikasi; Filosofi; Kebebasan Sosial; Struktur Sosial; Parasite.

\begin{abstract}
Human beings essentially have social freedom inherent in themselves. Parasite (2019), a film which raises social issues in South Korea, has a close relationship with the reality of social stratification in society. Using the film Parasite as a case study, this article attempts to trace the tendency of meaning production regarding the philosophy of human freedom. In the process, this article draws the conclusion that the depiction of a person within the social structure in the narrative element of the Parasite film can represent the meaning of social freedom which is also limited by other human freedoms.
\end{abstract}

Keywords: Communication; Philosophy; Social Freedom; Social Structure; Parasite

${ }^{1}$ Rifqi Nadhmy Dhia adalah Mahasiswa Pascasarjana Ilmu Komunikasi pada Fakultas Ilmu Sosial dan Ilmu Politik Universitas Indonesia (UI) Salemba.

${ }^{2}$ Firman Kurniawan adalah Staf Pengajar Pascasarjana Ilmu Komunikasi pada Fakultas Ilmu Sosial dan Ilmu Politik Universitas Indonesia (UI) Salemba. e-mail : rifqi.nadhmy@ui.ac.id

e-mail: firmankurniawan@yahoo.com 


\section{Pendahuluan}

Manusia sebagai suatu entitas pada hakikatnya memiliki kebebasan yang khas yaitu "Kebebasan Sosial", yang menurut Hegel (dalam Neuhouser, 2000). Diwujudkan hanya dalam masyarakat yang terstruktur secara rasional. Hegel kemudian mengenali dilema ini, dan cara untuk menyelesaikannya diperjelas dalam versi yang diperluas dari rumus yang dikutip sebelumnya, yang mendefinisikan kebebasan tidak hanya sebagai "berada dengan diri sendiri" tetapi sebagai "berada dengan diri sendiri di dalam yang lain" (Beisichselbstsein in einem Anderen).

Sementara itu Abazari (2020) dalam bukunya membahas konsep dialektis Marx tentang individu dan struktur sosial yaitu bahwa struktur sosial semata-mata dibentuk melalui tindakan individu, namun pada saat yang sama memiliki kehidupannya sendiri. Dari konsep inilah penulis berasumsi bahwa kebebasan sebagai esensi yang ada dari suatu Individu, yang kemudian secara tidak langsung berakibat bada terbentuknya suatu struktur sosial pada masyarakat.

Film Parasite yang dirilis tahun 2019 dan disutradarai oleh Bong Joon-Ho telah mendapat banyak penghargaan di beberapa festival film bergengsi, salah satunya yaitu Palme d'Or milik Cannes Film Festival 2019. Film ini merupakan film fiksi dengan genre Drama-Comedy-Thriller yang mengangkat tema besar isu sosial di Korea Selatan. Jalan ceritanya menceritakan kisah keluarga Kim yang berada pada kalangan menengah kebawah yang berusaha melawan takdir menaiki tangga sosial dengan bekerja pada keluarga Park yang jauh kontras berada pada kelas atas. Keluarga Kim dapat berhasil masuk secara perlahan ke lingkungan keluarga Park dengan cara memanipulasi identitas masing-masing dari mereka. Rencana mereka terlihat mulus di awal, namun ternyata keleluasaan mereka dibatasi oleh persaingan kepentingan yang terjadi dengan mantan keluarga pekerja lama yang sebelumnya mereka pikir telah mereka singkirkan. Mereka digambarkan memiliki keinginan dan potensi yang besar untuk melakukan suatu perubahan pada hidup mereka, tetapi masih sangat sulit bagi mereka hanya untuk bertahan hidup. Apa sebenarnya yang membuat mereka memiliki keterbatasan dalam struktur sosial yang ada? Bagaimana bisa manusia dilahirkan memiliki kebebasan namun hal tersebut juga membentuk suatu tatanan yang membatasi kebebasan mereka sendiri? Dalam artikel ini penulis akan menganalisis keterkaitan antara struktur sosial dengan kebebasan manusia melalui beberapa elemen cerita dalam film Parasite.

\section{Metode Penelitian}

Penulis menggunakan pendekatan interpretif dengan metode kualitatif deskriptif untuk dapat menjelaskan makna dari beberapa unsur naratif yang ada pada film Parasite melalui perspektif filsafat kebebasan manusia. Menurut Taylor, Bogdan, \& DeVault (2016), metodologi kualitatif mengacu pada arti yang paling luas pada penelitian yang menghasilkan data deskriptif, yaitu berupa kata-kata tertulis atau lisan dari orang-orang dan perilaku yang dapat diamati. Sedangkan teknik analisis wacana menurut Eriyanto (2006) dimaksudkan sebagai suatu analisis untuk membongkar maksud-maksud dan makna-makna tertentu. Dalam hal ini penulis menggunakan beberapa adegan pada film Parasite sebagai wacana yang akan dianalisis berdasarkan plots of thought (Crane, 1952) untuk menjawab pertanyaan penelitian.

\section{Hasil dan Pembahasan}

\section{Kebebasan Sosial}

Schopenhauer (dalam Janaway, 2002) 
mengungkapkan bahwa kesadaran diri setiap orang menegaskan dengan sangat jelas bahwa dia bisa melakukan apa yang dia mau. Tetapi karena kita sebagai manusia dapat membayangkan memiliki tindakan yang sangat berlawanan, maka jika dia berkehendak dia juga dapat melakukan yang sebaliknya Kebebasan sosial menunjukkan hubungan pengakuan yang bersifat mutual dengan perwujudan dalam berbagai bidang tindakan dan membentuk kehidupan etis. Gagasan utama di sini adalah kebebasan individu (otonomi, atau apa yang disebut Honneth dalam karya nya sebelumnya tentang 'practical relation-to-self') yang membutuhkan kondisi obyektif untuk realisasinya. Secara umum, kebebasan individu membutuhkan pengakuan timbal balik, yang 'mengacu pada pengalaman timbal balik dalam melihat diri kita sendiri dikonfirmasi dalam keinginan dan tujuan orang lain, karena keberadaan orang lain merupakan kondisi untuk memenuhi keinginan dan tujuan kita sendiri ( $\mathrm{Ng}, 2019)$.

Franz Magnis-Suseno (1987) dalam bukunya yang berjudul Etika Dasar menjelaskan bahwa manusia dapat dikatakan memiliki kebebasan sosial apabila ia memiliki kemungkinan-kemungkinan untuk bertindak tidak dibatasi secara sengaja orang lain. Karena kebebasan itu secara hakiki dihayati dalam hubungan dengan orang lain. Menurutnya kebebasan sosial terbagi menjadi 3 berdasarkan cara pembatasan, yaitu: (1) Jasmani, yang dibatasi dengan paksaan fisik; (2) Rohani, yang dibatasi melalui tekanan psikis; (3) Normatif, yang dibatasi melalui larangan dan kewajiban. Secara lebih lanjut, menurut Schoemann (1992) kebebasan sosial tidak bisa berarti kekebalan dari pengaruh dan tekanan sosial. Sebaliknya, kebebasan sosial tersedia sejauh ada pilihan di antara ikatan asosiatif, yang masing-masing secara tepat mengeksploitasi kekuatan sosial untuk menjaga koherensi dan efektivitas tindakan sosial.

\section{Struktur Sosial}

Ide tentang 'struktur sosial' pertama kali diperkenalkan oleh Herbert Spencer. Pada saat itu, kata 'struktur' dalam biologi mengacu pada apa yang sekarang kita sebut 'organ', yaitu kumpulan jaringan yang berdekatan yang melakukan fungsi yang dapat ditentukan untuk organisme secara keseluruhan. Spencer berpendapat bahwa masyarakat memiliki 'struktur sosial' yang menjalankan fungsi sosial. Dengan demikian, akar gagasan struktur sosial berasal dari metafora organisme yang diterapkan pada masyarakat (Martin \& Lee, 2015).

Secara lebih lanjut Martin \& Lee (2015) menyimpulkan dalam penelitiannya bahwa struktur sosial seringkali tampaknya berkonotasi dengan batasan tindakan individu, tetapi itu sendiri tidak lain adalah serangkaian tindakan. Ini secara teratur bertentangan dengan budaya, tetapi secara teratur tampaknya hanya menjadi sisi kedua dari koin yang sama dengan budaya. Mungkin yang terbaik yang dapat dikatakan adalah bahwa itu tampaknya menjadi ide yang tidak dapat kita lakukan tanpanya.

Pola sosial, institusi, dan organisasi hanyalah abstraksi dari perilaku individu dan ringkasan dari sebaran micro-behavior yang berbeda dalam ruang dan waktu. Abstraksi dan ringkasan ini tidak melakukan apapun; jika mereka tampaknya menunjukkan realitas yang berkelanjutan itu karena individu yang membentuk mereka mengulangi perilaku mikro mereka berkali-kali, dan jika 'struktur' berubah adalah karena individu yang memberlakukannya mengubah perilaku mikro mereka. Struktur sosial adalah salah satu konsep paling sentral dalam sosiologi. Namun ada ketidaksepakatan yang luas tentang apa artinya. Ketidaksepakatan ini konsekuensial karena perbedaan dalam cara sosiolog mengkonseptualisasikan struk- 
tur sosial mengarah pada pendekatan sosiologi yang sangat berbeda (Porpora, 1989).

Dalam penelitiannya Porpora (1989) juga membuat acuan pandangan tentang struktur sosial sebagai salah satu dari berikut ini: (1) Pola perilaku agregat yang stabil dari waktu ke waktu; (2) Keteraturan seperti hukum yang mengatur perilaku fakta sosial; (3) Sistem hubungan manusia di antara posisi sosial; (4) Aturan dan sumber daya kolektif yang menyusun perilaku.

\section{Unsur Naratif Film}

Susanne Langer (dalam Ali, 2017) menyatakan bahwa struktur sebuah film atau motion picture berbeda dari struktur sebuah pentas drama; film lebih dekat dengan 'naratif' dari pada drama. Narasi adalah cara mendasar manusia memahami dunia. Prevalensi cerita dalam hidup kita adalah salah satu alasan mengapa kita perlu mencermati bagaimana film dapat mewujudkan bentuk naratif. Ketika kita berbicara tentang "pergi ke bioskop", yang kita maksudkan adalah kita akan menonton film naratif - film yang menceritakan sebuah cerita . Kita dapat menganggap narasi sebagai rangkaian peristiwa dari hubungan sebab-akibat yang terjadi dalam ruang dan waktu. Narasi adalah apa yang biasanya kita maksud dengan istilah cerita, meskipun kita akan menggunakan cerita dengan cara yang sedikit berbeda nanti. Biasanya, narasi dimulai dengan satu situasi; serangkaian perubahan terjadi menurut pola sebab dan akibat; dan sebagai penutup, situasi baru muncul yang mengakhiri narasi. Keterlibatan kita dengan cerita bergantung pada pemahaman kita tentang pola perubahan dan stabilitas, sebab dan akibat, waktu dan ruang (Bordwell \& Thompson, 2008).

Tentang pola perubahan tersebut, secara lebih khusus suatu naratif dalam film dapat dilihat melalui analisis plots of thought, yaitu proses perubahan pemikiran tokoh utama dengan segala konsekuensi dalam perasaannya, berdasarkan kondisi langsung yang dihadapi (Crane, 1952). Dalam hal ini penulis akan berpusat pada pemikiran Keluarga Kim.

\section{Angan-Angan Keluarga Kim}

"Struktur sosial itu ada. Diciptakan oleh manusia, tetapi kemudian ia memiliki kehidupannya sendiri. Setelah ditetapkan sebagai entitas yang berdiri sendiri, struktur sosial menjadi kekuatan yang sangat kuat dalam menentukan kehidupan orang yang menciptakannya."

(Babbie, 1994, hal.19)

Film Parasite memang dari awal sangat terlihat berbicara tentang stratifikasi sosial. Pembuka dari dari film ini pun memperlihatkan latar sosial keluarga Kim sebagai keluarga yang hidup pada strata kelas bawah. Hal ini digambarkan dengan banyak elemen pada adegan pembuka tersebut bahkan dengan letak rumah dari keluarga kim yang berada setengah di bawah permukaan tanah. Keluarga Kim diceritakan kewalahan dalam bertahan hidup ditengah kesulitan ekonomi. Namun dilain sisi masing-masing dari anggota keluarga kim memiliki potensi kemampuan diri yang baik. Misalnya Choong-Sook sang ibu dulunya adalah atlet lempar lembing yang meraih penghargaan. Atau juga Ki Jung, anak perempuan yang cerdik dalam mengatur strategi dan memiliki jiwa seni. Kadang mereka seperti terlihat terjebak dalam struktur sosial yang ada dan tidak memiliki kebebasan untuk merubah nasib mereka.

Schopenhauer (dalam Janaway, 2002) mengungkapkan bahwa dalam realita kehidupan dari hampir semua orang; mereka memiliki keinginan, mereka tahu apa yang mereka inginkan, dan mereka 
berjuang setelahnya dengan kesuksesan yang cukup untuk melindungi mereka dari keputusasaan, dan kegagalan yang cukup untuk melindungi mereka dari kebosanan, serta konsekuensinya.

Korban dari kontradiksi antara penekanan budaya pada ambisi uang dan jeratan sosial tidak selalu menyadari sumber struktural yang menggagalkan aspirasi mereka; Dan mereka yang menemukan sumber dalam struktur sosial mungkin menjadi terasing dari struktur itu dan menjadi calon yang siap untuk adaptasi. Adaptasi tersebut dapat berupa pemberontakan. Sementara itu, kelompok yang lain dan ini tampaknya mencakup sebagian besar, mungkin menghubungkan kesulitan mereka dengan sumber yang lebih mistis dan kurang sosiologis (Merton, 1968). Keluarga Kim pada fase-fase dan perkembangannya dalam plot cerita Parasite secara tidak langsung menggambarkan semua keadaan itu.

Monisme menolak konsep tujuan di setiap bidang, kecuali tindakan manusia. Ia mencari hukum alam, tetapi bukan untuk tujuan alam. Tujuan alam adalah asumsi sewenang-wenang yang tidak kurang dari kekuatan tak terlihat. Melalui pandangan monismenya, Steiner \& Lipson (1995) memaparkan bahwa, bahkan tujuan hidup yang tidak ditetapkan oleh manusia sendiri adalah asumsi yang tidak dapat dibenarkan. Tidak ada yang memiliki tujuan kecuali apa yang pertama kali dibuat oleh manusia, karena tujuan hanya muncul melalui realisasi sebuah ide. Dalam pengertian yang realistis, sebuah ide hanya bisa menjadi efektif pada manusia. Oleh karena itu, kehidupan manusia hanya dapat memiliki tujuan dan pengaturan takdir yang diberikan manusia itu. Untuk pertanyaan: Apa tugas manusia dalam hidup? Monism hanya dapat menjawab: Tugas yang dia tentukan sendiri. Misi saya di dunia tidak ditentukan sebelumnya, tetapi setiap saat adalah yang saya pilih untuk diri saya sendiri. Saya tidak memulai per- jalanan saya melalui hidup dengan perintah berbaris tetap. Ide-ide direalisasikan dengan sengaja hanya oleh manusia. Oleh karena itu, tidak boleh berbicara tentang perwujudan gagasan oleh sejarah. Semua frase seperti "sejarah adalah evolusi umat manusia menuju kebebasan," atau "... realisasi tatanan dunia moral," dan seterusnya, dari sudut pandang monistik, tidak dapat dipertahankan.

Kembali pada unsur cerita dalam film ini, Ki-Woo, anak laki-laki dari keluarga kim dari awal cerita digambarkan cukup banyak memiliki angan-angan. Selain Ki-Woo sangat ingin melanjutkan pendidikannya di universitas ternama. Setelah bekerja menjadi guru bahasa Inggris untuk Da-hye, anak perempuan dari keluarga Park yang kaya raya, tak disangka Da-Hye jatuh cinta padanya. Ki-woo pun menjadi memiliki angan-angan untuk menikahi putri keluarga yang kaya raya tersebut. Namun dalam satu adegan, ia bertanya pada dirinya sendiri sambil berbicara pada Da-hye dan memandangi orang-orang kaya yang sedang berpesta, "Orang-orang ini begitu santai walaupun pada acara yang mendadak, apakah aku cocok berada disini?”. Pada adegan tersebut Ki-woo mempertanyakan apakah jika ia menikahi Da-hye di kemudian hari, ia dapat berbaur dengan lingkungan orangorang kelas atas. Sedangkan ia berasal dari keluarga kelas bawah. Ia memiliki tekad yang kuat dan sudah mendapatkan cinta dari Da-hye namun seperti ada status sosial diluar diri Ki-woo yang membatasi niatnya.

Pertanyaan yang lebih dalam, bagaimanapun adalah 'Apakah saya memiliki kebebasan untuk memilih tindakan ini atau itu?'. Pertanyaan ini juga dilontarkan oleh Schopenhauer (dalam Janaway, 2002) yang menjelaskan perbedaan yang sering diabaikan, antara kebebasan berkehendak dan kebebasan untuk bertindak. Kebebasan untuk bertindak adalah kemampuan untuk melakukan 
sesuatu, jika seseorang mau melakukannya. Kebebasan ini dapat dihilangkan oleh hambatan eksternal untuk bertindak, dengan membatasi motif, hukum atau ancaman dari berbagai konsekuensi jika seseorang bertindak, atau dengan gangguan kemampuan kognitif subjek.

Mill (dalam Schoemann, 1992) juga memiliki perhatian mengenai tirani sosial. Mill sangat prihatin dengan tekanan informal atau sosial pada individu untuk membuat hidup mereka harus sesuai dengan model yang disetujui oleh sistem sosial. Dia mencatat bahwa tekanan sosial bisa lebih meresap, tak henti-hentinya, dan menghancurkan daripada ancaman hukum. Dan akibatnya, lebih merusak kepribadian manusia. Masyarakat dapat dan memang menjalankan mandatnya sendiri ; dan jika seseorang mengeluarkan hal-hal salah yang seharusnya tidak dicampuri, sistem ini akan mempraktekkan suatu tirani sosial yang lebih tangguh daripada politik penindasan. Karena meski tidak ditegakkan dengan hukuman yang ekstrim, tapi menyisakan lebih sedikit cara untuk melarikan diri, menembus banyak lebih dalam ke detail kehidupan, dan memperbudak jiwa.

\section{Persaingan Antar Parasit}

Seluruh anggota keluarga Kim diceritakan berhasil menduduki pekerjaan di rumah keluarga Park. Mungkin pada awalnya penonton akan merasa bahwa keluarga Kim lah yang cocok mendapat predikat sebagai 'parasit' dalam plot cerita ini. Namun ternyata mereka menemukan bahwa Choong-sook, bekas asisten rumah tangga keluarga park yang pekerjaannya mereka singkirkan, menyembunyikan suaminya di bunker rumah tersebut selama bertahun-tahun. Pada adegan tersebut Choong-sook memohon kepada keluarga park agar membolehkan suaminya tinggal di bunker rumah tersebut. Mereka pun bersaing karena Choong-sook selanjutnya secara tidak sengaja mengetahui informasi bahwa keluarga Kim memalsukan identitas mereka di depan keluarga Park.

Dengan demikian, kebebasan yang sudah mereka raih dalam rumah tersebut sama-sama dalam ambang kejatuhan. Pun ketika dilihat dari sisi lain, kadang terasa seperti paradoks jika mengingat keluarga Park juga begitu membutuhkan para asisten rumah tangganya untuk menyelesaikan urusan mereka, bahkan untuk urusan yang sepele mereka harus mengandalkan orang lain. Kebebasan dari masing-masing keluarga disini dibatasi oleh kebebasan keluarga yang lain. Jika melihat dari sudut pandang tokoh utama, kebebasan dari keluarga Kim disini membutuhkan pengakuan timbal balik dari keluarga lain yang ada di rumah tersebut, karena keberadaan keluarga lain merupakan kondisi untuk memenuhi keinginan dan keluarga Kim.

Adegan ini terkait dengan pernyataan yang diungkapkan oleh Babbie (1994), bahwa struktur sosial terbentuk dari kebebasan yang dimiliki tiap individu. Kebebasan yang diserahkan adalah substansi dari masyarakat. Jika kita akan menciptakan beberapa struktur sosial baru, kita perlu membuat setiap manusia melepaskan sebagian dari kebebasan mereka - beberapa opsi dan kemungkinan yang sebaliknya akan mereka nikmati. Kebenarannya adalah, tentu saja, kita telah menciptakan struktur sosial sepanjang hidup kita, dan kita telah melakukannya dengan membuat manusia lain menyerahkan sebagian dari kebebasan mereka. Kebebasan bagi beberapa pihak, seperti yang dilihat Beauvoir (2016), juga merupakan sumber pembatasan bagi yang lain (atau, lebih tepatnya, marginalisasi bagi yang lain). Dan dilihat dari sudut pandang ilmu sosial, inilah ruang identitas sosial. 


\section{Kesimpulan}

"Ki-woo, you know what kind of plan never fails? No plan at all. No plan. You know why? If you make a plan, life never works out that way. Look around us, did these people think 'Let's all spend the night in a gym?' But look now, everyone's sleeping on the floor, us included. That's why people shouldn't make plans. With no plan, nothing can go wrong and if something spins out of control, it doesn't matter."

Dialog diatas yang dilontarkan oleh Kim Ki-taek, Ayah dari Ki-woo dari keluarga Kim, seperti menangkap kembali semua adegan dalam cerita di film Parasite, dan begitu membuat penonton berpikir sejenak mengapa hidup dalam dunia nyata kadang kala juga memberikan situasi demikian. Namun ketika hidup seolah-olah memberi kita tekanan, bukan berarti kita tinggal mengikuti arus. Jelas memang manusia harus menerima bahwa kebebasan mereka dibatasi, namun itu lah yang menjadi perjuangan untuk dipertanggungjawabkan. Jika dilihat secara keseluruhan, cerita dalam film ini walaupun bukan memiliki inti pesan tentang hal tersebut, namun berhasil menggambarkan bahwa seseorang, ketika hidup dan memiliki tujuan ataupun keinginan, dalam rencana dan usaha yang dimilikinya pasti membutuhkan bantuan dari manusia lain, itu yang membuat ia harus merelakan bagian dari kebebasan sosial yang melekat pada dirinya. Kemudian dengan setiap manusia berada pada kondisi yang sama maka terbentuklah suatu struktur timbal balik sebagai hasil konsekuensi akan terbatasnya kebebasan tersebut.

\section{Referensi}

Abazari, A. (2020). Hegel's Ontology of Power: The Structure of Social Domination in Capitalism. Cambridge: Cambridge University Press.

Ali, M. (2017). Moving Image Theory: Sebuah Pengantar Teori Film. Sanggar Luxor.

Babbie, E. R. (1994). What is society? Reflections on freedom, order, and change Thousand Oaks, CA: SAGE Publications, Inc. doi: 10.4135/9781483326498

Bordwell, D., \& Thompson, K. (2008). Film art: An introduction. Boston: McGraw Hill.

Crane, R. S. (1952). The concept of plot and the plot of Tom Jones. The Novel: An Anthology of Criticism and Theory 1900-2000, 119-40.

Eriyanto. (2006). Analisis Wacana: Pengantar Analisis Teks Media. Yogyakarta: LkiS

Janaway, C. (2002). Schopenhauer: A Very Short Introduction. Oxford: Oxford University Press.

Magnis-Suseno, F. (1987). Etika dasar: Masalah-masalah pokok filsafat moral. Yogyakarta: Kanisius.

Martin, J \& Lee, M. (2015). Social Structure. International Encyclopedia of the Social \& Behavioral Sciences, 22(2), 713-718 https://doi.org/10.1016/ B978-0-08-097086-8.32154-7

Merton, R. K. (1968). Social theory and social structure. New York: Free Press.

Neuhouser, F. (2000). Foundations of Hegel's social theory: Actualizing freedom. Cambridge, Mass: Harvard University Press. 
$\mathrm{Ng}$, K. (2019). Social freedom as ideology. Philosophy \& Social Criticism, 45(7), 795-818. https://doi. org/10.1177/0191453718814877

Porpora, D. V. (1989). Four concepts of social structure. Journal for the Theory of Social Behaviour, 19(2), 195-211.

Schoeman, F. (1992). Privacy and Social Freedom (Cambridge Studies in Philosophy and Public Policy). Cambridge: Cambridge University Press. doi:10.1017/CBO9780511527401

Steiner, Rudolf, \& Lipson, Michael. (1995). Intuitive Thinking as a Spiritual Path: A Philosophy of Freedom. Hudson, N.Y.: Anthroposophic Press.

Taylor, S. J., Bogdan, R., \& DeVault, M. L. (2016). Introduction to qualitative research methods: A guidebook and resource. Hoboken, New Jersey: JohnWiley \& Sons, Inc.

Thalos, M. (2016). A Social Theory of Freedom. New York: Routledge. 